\title{
Kajian Ekstraksi Komponen Aromatik Bunga Kopi Robusta (Coffea chanepora)
}

\section{Study of Extraction of Aromatic Components of Robusta Coffee Flower (Coffea chanepora)}

\author{
Suci Hardina Rahmawati ${ }^{1}$, Tanto Pratondo Utomo ${ }^{2}$, Sri Hidayati ${ }^{1}$, Erdi Suroso ${ }^{2}$ \\ 1 Jurusan Magister Teknologi Industri Pertanian, Fakultas Pertanian Universitas Lampung \\ 2 Jurusan Teknologi Hasil Pertanian, Fakultas Pertanian Universitas Lampung \\ "Email: tanto.utomo@fp.unila.ac.id
}

\begin{abstract}
Abstrak: Provinsi Lampung adalah wilayah yang potensial untuk mengembangkan tanaman perkebunan. Salah satu tanaman perkebuan yang sangat terkenal dan menjadi ciri khas adalah kopi. Kopi merupakan komoditi masyarakat Lampung yang sangat potensial dan perlu dikembangkan lebih lanjut agar memiliki nilai tambah. Berdasarkan data dari BPS provinsi Lampung, produksi kopi yang sangat tinggi menyebabkan ketersediaan bunga kopi yang melimpah. Melimpahnya bunga kopi inilah yang melatar belakangi penelitian ini, selain itu belum pernah ada yang melakukan penelitian mengenai teknik ekstraksi dan karakteristik yang terdapat dalam komponen aromatik bunga kopi. Berdasarkan hasil penelitian diperoleh rendemen yang paling tinggi dengan dengan metode enflurasi, akan tetapi aroma yang dihasilkan hanya menyerupai bunga kopi sehingga metode terbaik untuk ekstraksi bunga kopi adalah dengan metode hydrosol. Aroma yang dihasilkan dengan metode hydrosol sangat menyerupai bunga kopi.
\end{abstract}

Kata kunci: Bunga kopi, Ekstraksi, Komponen aromatik

Abstract: Lampung Province is a potential area for developing crops plantation. One of the most well-known crops plantation in Lampung Province is coffee and needs to be developed further in order to have more added value. The high coffee production causes the availability of abundant coffee flowers. The abundance of coffee flowers was the background of this research, besides that no one has ever done research on the extraction techniques and characteristics contained in the aromatic components of coffee flowers. Te research results showed that the highest yield with the method of enfluration, but the resulting aroma only resembles coffee flowers so that the best method for extracting coffee flowers is the hydrosol method. The aroma produced by the hydrosol method closely resembles coffee flowers.

Keywords: Coffee flowers, extraction, Aromatic Components 


\section{PENDAHULUAN}

Provinsi Lampung adalah wilayah yang potensial untuk mengembangkan tanaman perkebunan. Salah satu tanaman perkebuan yang sangat terkenal dan menjadi ciri khas adalah kopi. Kopi merupakan komoditi masyarakat Lampung yang sangat potensial dan perlu dikembangkan lebih lanjut agar memiliki nilai tambah. Luas perkebunan kopi dilampung $173.630 \mathrm{Ha}$, dengan produksi kopi mencapai 131.501 ton per tahun (BPS propinsi Lampung, 2017).

Berdasarkan data dari BPS provinsi Lampung, produksi kopi yang sangat tinggi menyebabkan ketersediaan bunga kopi yang melimpah. Melimpahnya bunga kopi inilah yang melatar belakangi penelitian ini, selain itu belum pernah ada yang melakukan penelitian mengenai teknik ekstraksi dan karakteristik yang terdapat dalam komponen aromatik bunga kopi.

Dewasa ini belum banyak yang mengetahui bahwa bunga kopi memiliki kandungan minyak atsiri. Bunga kopi memiliki aroma ketika belum mengalami penyerbukan. Hal ini menandakan bahwa bunga kopi memiliki minyak atsiri yang cukup potensial apabila dimanfaatkan (Fajrin, 2017).

Bunga kopi belum pernah dimanfaatkan seperti bunga bunga yang lainnya seperti mawar,melati,kenanga dan bunga- bunga yang lainnya untuk diekstraksi, sehingga dapat dimanfaatkan menjadi parfum, aromaterapi, maupun produk lainnya. Bunga kopi hampir mirip dengan melati, mahkotanya berwarna putih dan berbau harum semerbak. Kelopak bunga berwarna hijau, pangkalnya menutupi bakal buah yang mengandung dua bakal biji. Bunga kopi biasanya akan mekar pada permulaan musim kemarau sehingga pada akhir musim kemarau telah berkembang menjadi buah yang siap dipetik. Berdasarkan hasil penelitian (Nohara et al, 1997) kandungan minyak atsiri bunga kopi Arabica $L$, menunjukkan adanya sejumlah besar senyawa aromatik yang mengandung nitrogen dan juga turunan fenitana. Epoxygeraniol novel (2,3-epoxygeraniol dan 6,7-epoxygeraniol) Epoxygeraniol dan Epoxynerol.

Proses ekstraksi minyak atsiri dapat dilakukan dengan beberapa cara yaitu dengan penyulingan, ekstraksi dengan pelarut menguap, ekstraksi dengan lemak dingin, dan ekstraksi dengan lemak panas (Manurung 2010). Metode tersebut dapat menghasilkan rendemen dan karakteristik yang berbeda. Adapun tujuan dilakukannya penelitian ini untuk Mengetahui pengaruh perbedaan cara ekstraksi terhadap rendemen minyak atsiri bunga kopi dan komponen kimia hasil ekstraksi minyak atsiri bunga kopi.

\section{METODE PENELITIAN}

Penelitian ini akan dilaksanakan pada april sampai juli 2019 dan bertempat di Laboratorium Mutu dan Pengujian Hasil, Universitas Lampung.

\section{Bahan}

Bahan baku yang digunakan adalah bunga kopi yang masih di pohon yang dipetik setelah masa penyerbukan telah usai berwarna putih segar dan belum teroksidasi. Diperoleh dari Bumi Jawa Batanghari Nuban Lampung Timur, Dono Arum Seputih Agung Lampung Tengah dan SB9, Seputih Banyak, Lampung Tengah dengan jenis kopi yang sama yaitu robusta dan Mentega putih untuk bahan maserasi. Bahan kimia yang digunakan adalah $n$-heksan yang diperoleh dari laboratoium Mutu dan Penngujian Hasil Pertanian Universitas Lampung. 
Alat

Alat yang digunakan adalah Rotary evaporation, oven (memert,jerman), neraca analitik (Bosh, Jerman), refraktometer (Kikuchi, Jepang), pipet gondok,gelas ukur ,gelas arloji, gas kromatografi, water bath, gelas piala, Erlenmeyer dan alat penunjang lainnya.

\section{Pelaksanaan penelitian}

Penelitian ini menggunakan bahan baku bunga kopi dengan tiga ulangan. Data dilakukan dengan analisis deskriptif. Dalam penelitian ini ada proses ekstraksi yaitu :

Proses ekstraksi dengan cara hydrodisfusion (Hydrodisfusion Extraction).

Menimbang bunga kopi sebanyak 50 gram kemudian bunga kopi dimasukkan kedalam labu ukur, setelah itu labu ukur dipasang pada alat ekstraksi yaitu rotary evaporation,ekstraksi dilakukan pada suhu $40^{\circ} \mathrm{C}$ selama 30 menit.

\section{Proses ekstraksi dengan maserasi}

Menimbang bunga kopi sebanyak 150 gram dibagi menjadi 3 masing masing 50 gram dan mentega putih 300 gram. Kemudian mentega putih ditaruh diatas Loyang diratakan. Bunga kopi sebanyak 150 gram diletakkan diatas Loyang yang berisi metega putih selanjutnya Loyang ditutup dengan aluminium foilselama 24 jam. Setelah 24ditambahkan lagi 25 gram sampai 24 jam yg terakir.

Setelah perendaman selama $3 \times 24$ jam kemudian memisahkan mentega dengan bunga kopi secara manual dengan pinset. Jika sudah terpisah mentega putih direndam kedalam n-Heksan sebanyak $200 \mathrm{ml}$ ditutup kembali dengan aluminium foil dan perendaman dilakukan selama 24 jam.

Setelah perendaman kemudian larutan n-Heksan dan mentega dipisahkan kembali dengan kertas saring. Larutan hasil penyaringan kemudian di ekstraksi ke dalam rotary evaporation dengan suhu $40^{\circ} \mathrm{C}$ selama 30 menit.

\section{Proses ekstraksi dengan menggunakan pelarut}

Menimbang bunga kopi sebanyak 50 gram dan n-Heksan 200 ml kemudian bunga kopi dimasukkan kedalam labu ukur direndam kedalam larutan etanol dan ditutupdengan aluminium foil disimpan kedalam lemari pendingin. Perendaman dilakukan selama 24 jam. Setelah perendaman bunga kopi dan n-Heksan dipisahkan, setelah dipisahkan larutan n-Heksan tersebut diekstraksi kedalam rotary evaporation dengan suhu $40^{\circ} \mathrm{C}$ selama 30 menit.

\section{Uji Organoleptik}

Pengujian organoleptik minyak bunga kopi berupa warna dan bau dilakukan dengan uji langsung menggunakan indera penglihatan dan penciuman yang dilakukan oleh petani kopi yang berpengalaman. Pengukuran indek bias minyak bunga kopi dilakukan dengan menggunakan hand-refraktrometer $\mathrm{N}-3000 \mathrm{e}$ (Atago Co. Ltd, Tokyo, Jepang) .

\section{Analisis GC-MS}

Komposisi kimia minyak bunga kopi dianalisis menggunakan alat Gas Chromatography-Mass Spectrometry (GC-MS) QP5050A (Shimadzu Co. Ltd, Kyoto, Jepang). Hasil analisa komponen kimia yang terkandung dalam minyak bunga kopi 
dibaca melalui analisis kromatogram dengan membandingkan waktu retensi dengan indek retensi Kovats, membandingkan dengan pustaka yang ada.

\section{HASIL DAN PEMBAHASAN}

\section{Rendemen Sebelum Penyerbukan}

Optimasi rendemen minyak atsiri bunga kopi diperoleh dari hasil ekstraksi 3 metode, yaitu hydrosol, Enflurasi dan maserasi. Rendemen dihitung dari berat minyak awal yaitu berat ekstrak dibagi berat bahan dikalikan 100 persen. Rendemen bunga kopi sebelum penyerbukan

Tabel 1. Tabel rendemen bunga kopi sebelum penyerbukan.

\begin{tabular}{ccccc}
\hline No & METODE & $\begin{array}{c}\text { HASIL } \\
\text { EKSTRAKSI } \\
\text { (gram) }\end{array}$ & $\begin{array}{c}\text { RENDEMEN } \\
(\%)\end{array}$ & $\begin{array}{c}\text { RATA-RATA } \\
(\%)\end{array}$ \\
\hline 1 & Hidrosol-1 & 8,75 & 17,50 & \\
2 & Hidrosol-2 & 6,87 & 13,74 & 16,10 \\
3 & Hidrosol-3 & 8,54 & 17,08 & \\
4 & Maserasi-1 & 6,83 & 13,66 & 13,28 \\
5 & Maserasi-2 & 5,86 & 11,72 & \\
6 & Maserasi-3 & 7,23 & 14,46 & \\
7 & Enflurasi-1 & 11,45 & 22,90 & \\
8 & Enflurasi-2 & 10,44 & 20,88 & \\
9 & Enflurasi-3 & 9,87 & 19,74 & \\
\hline
\end{tabular}

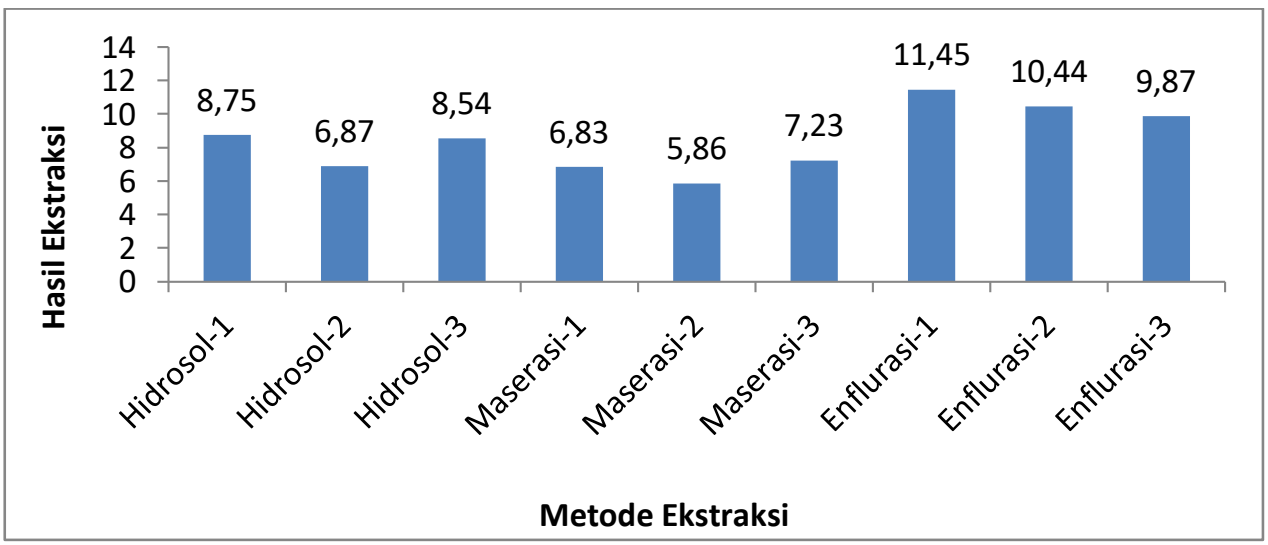

Gambar 1. Grafik perolehan rendemen bunga kopi sebelum penyerbukan.

Dari table diatas diperoleh bahwa rendemen minyak bunga kopi sebelum penyerbukan dengan metode hydrosol diperoleh rendemen rata-rata $16.10 \%$, metode maserasi $13.28 \%$ dan metode enflurasi $21.17 \%$. Rendemen rata- rata setelah penyerbukan metode hydrosol 12.09\%, Maserasi 12,91\% dan enflurasi $16.11 \%$.

Rendemen tertinggi diperoleh dengan metode enflurasi dengan mentega putih, hal ini dikarenakan mentega putih memiliki konsistensi yang tepat tidak terlalu lunak maupun keras serta tidak berbau dan berasa hambar sehingga proses penyerapan aroma lebih baik. Proses enflurasi menghasilkan minyak dengan rendemen lebih banyak dan minyak yang dihasilkan lebih wangi dibandingkan dengan ekstraksi pelarut menguap (Guenther, 1987). 
Rendemen minyak bunga kopi paling banyak diperoleh dengan metode enflurasi akan tetapi aroma yang di hasilkan hanya menyerupai bunga kopi pada saat sebelum penyerbukan.

\section{Rendemen Setelah penyerbukan}

Rendemen bunga kopi setelah penyerbukan adalah sebagai berikut disajikan dalam table dan grafik. Tabel Rendemen Bunga Kopi Setelah penyerbukan.

Tabel 2: Tabel Rendemen Bunga Kopi Setelah penyerbukan

\begin{tabular}{ccccc}
\hline No & METODE & $\begin{array}{c}\text { HASIL } \\
\text { EKSTRAKSI } \\
(\mathbf{g r a m})\end{array}$ & $\begin{array}{c}\text { RENDEMEN } \\
(\%)\end{array}$ & $\begin{array}{c}\text { RATA-RATA } \\
(\%)\end{array}$ \\
\hline 1 & Hidrosol-1 & 6,05 & 12,10 & \\
2 & Hidrosol-2 & 6,32 & 12,64 & 12,09 \\
3 & Hidrosol-3 & 5,82 & 11,63 & \\
4 & Maserasi-1 & 6,27 & 12,54 & 12,91 \\
5 & Maserasi-2 & 6,74 & 13,48 & \\
6 & Maserasi-3 & 6,35 & 12,70 & \\
7 & Enflurasi-1 & 8,76 & 17,52 & 16,11 \\
8 & Enflurasi-2 & 7,88 & 15,76 & \\
9 & Enflurasi-3 & 7,53 & 15,06 & \\
\hline
\end{tabular}

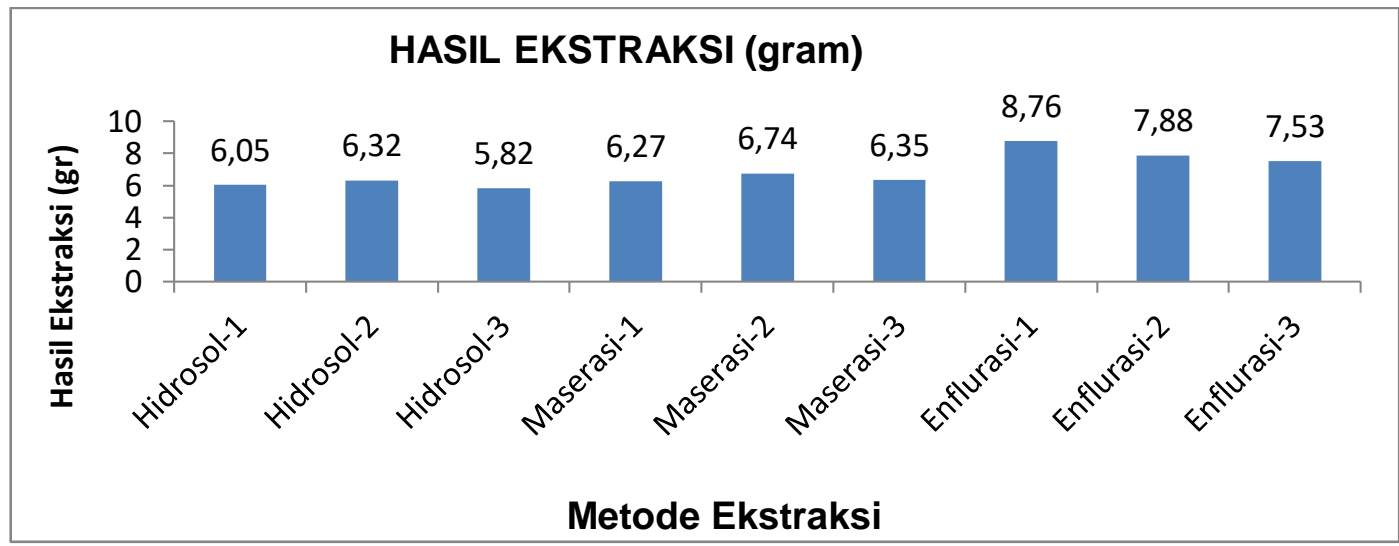

Gambar 2. grafik perolehan rendemen bunga kopi setelah penyerbukan

Dari table diatas diperoleh bahwa rendemen minyak bunga kopi setelah penyerbukan dengan metode hydrosol $12.09 \%$, Maserasi $12,91 \%$ dan enflurasi $16.11 \%$.

Rendemen minyak bunga kopi lebih banyak sebelum penyerbukan hal ini dikarenakan kondisi kelopak bunga yang mekar dengan sempurna, bunga masih terlihat putih segar belum teroksidasi dan aroma bunga kopi yang masih harum dan mewangi.

Metode ekstraksi dengan pelarut menguap dengan pelarut $\mathrm{N}$-Heksan nilai rendemen sebelum penyerbukan adalah $13.28 \%$ dan setelah penyerbukan adalah $12.91 \%$. Pelarut $\mathrm{n}$-heksan adalah pelarut paling baik untuk ekstraksi minyak bunga kopi, hal ini dikarenakan sifatnya yang selektif dalam melarutkan senyawa yang terkandung dalam komponen minyak bunga kopi dan zat warna dalam jumlah sedikit.

Dalam penelitian ini hasil ekstraksi dengan pelarut $n$-Heksan menghasilkan ekstrak dengan cairan berwarna kekuningan dengan aroma yang sangat sedikit bahkan sangat tidak mendekati aroma bahan baku, hal ini dikarenakan pelarut $\mathrm{n}$ heksan menghilangkan aroma asli bunga kopi. 
Hidrosol mengandung semua unsur kimia yang larut dalam air dari bagian tumbuhan yang disuling. Metode ekstraksi dengan hydrosol pada bunga kopi dapat menyerap aroma pada bunga kopi dengan sempurna dibandingkan dengan metode enflurasi dan maserasi.

Penyerapan aroma bunga kopi dengan metode hydrosol adalah yang paling sempurna hal ini dikarenan senyawa hasil ekstraksi pada ekstrak bunga kopi larut dalam air.

\section{Indeks Bias}

Penentuan indeks bias dilakukan dengan refraktometer padasuhu $20^{\circ} \mathrm{C}$. Nilai Indeks bias dipengaruhi salah satunya dengan adanya air dalam minyak. Semakin banyak kandungan minyaknya semakin kecil nilai indeks bias, hal ini dikarenakan sifat air yang mudah membiasakan cahaya yang datang.

Tabel 3. indeks bias minyak bunga kopi.

\begin{tabular}{ccc}
\hline No & NAMA SAMPEL & NILAI nD \\
\hline 1 & Maserasi Sebelum Penyerbukan & 1,464 \\
2 & Maserasi Setelah Penyerbukan & 1,348 \\
3 & Hidrosol Sebelum Penyerbukan & 1,333 \\
4 & Hidrosol Setelah Penyerbukan & 1,344 \\
5 & Enflurasi Sebelum Penyerbukan & 1,337 \\
6 & Enflurasi Setelah Penyerbukan & 1,458 \\
\hline
\end{tabular}

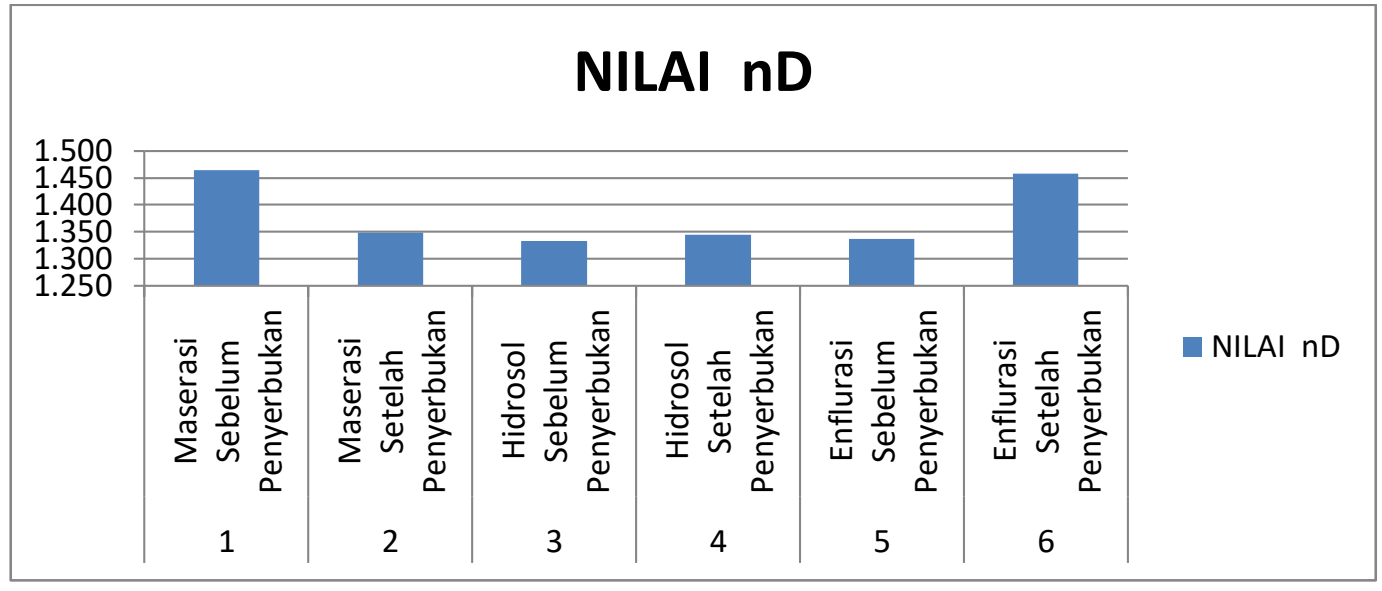

Gambar 3. Nilai indeks bias minyak bunga kopi.

\section{Uji Organoleptik}

Hasil pengujian organoleptik minyak bunga kopi berupa warna dan bau dilakukan dengan uji langsung menggunakan indera penglihatan dan penciuman yang dilakukan oleh petani kopi yang berpengalaman. Hasil uji organoleptik terhadap aroma minyak bunga kopi sebelum penyerbukan.

Tabel 4 menunjukkan bahwa ekstraksi dengan metode hydrosol aroma bunga kopi tampak sangat menyerupai bahan baku. Hasil dari metode hydrosol berupa water aromatic yang aroma dan baunya sangat menyerupai bunga kopi, hal ini dikarenakan prosesnya dikontakkan dengan uap air dengan suhu pada rotary evaporation $50^{\circ} \mathrm{C}$.

Metode maserasi atau perendaman larutan yang digunakan adalah pelarut $\mathrm{n}$ heksan,.Aroma bunga kopi yang mudah menguap jika diikat dengan $\mathrm{n}$ heksan 
aroma bunga kopi ada sebagian yang menguap ada sebagian yang terikat dengan $n$ heksan.

Tabel 4. Tabel hasil uji organoleptik minyak Bunga Kopi Sebelum penyerbukan.

\begin{tabular}{cccccc}
\hline No & Metode & Jumlah & Rata-rata & Skor & Keterangan \\
\hline 1 & Hidrosol-1 & 23 & 4,6 & 5 & Sangat menyerupai \\
2 & Hidrosol-2 & 23 & 4,6 & 5 & Sangat menyerupai \\
3 & Hidrosol-3 & 23 & 4,6 & 5 & Sangat menyerupai \\
4 & Maserasi-1 & 12 & 2,4 & 2 & Tidak menyerupai \\
5 & Maserasi-2 & 12 & 2,4 & 2 & Tidak menyerupai \\
6 & Maserasi-3 & 12 & 2,4 & 2 & Tidak menyerupai \\
7 & Enflurasi-1 & 18 & 3,6 & 4 & Menyerupai \\
8 & Enflurasi-2 & 18 & 3,6 & 4 & Menyerupai \\
9 & Enflurasi-3 & 18 & 3,6 & 4 & menyerupai \\
\hline
\end{tabular}

Metode enflurasi dengan mentega putih lebih baik jika dibandingkan dengan maserasi,hal ini dikarenakan aroma mentega putih yang netral sehingga dapat mengikat aroma dari bunga kopi dengan lebih baik.

\section{Komponen Senyawa}

\section{Metode Enflurasi}

Berdasarkan kromatogram pada bunga kopi terdeteksi 38 puncak dimulai dari komponen volatile nomor 1 yang muncul pada waktu retensi 5 menit dengan $\%$ area 20,66. Komponen pertama tersebut adalah 4-Hyroxybenzothiophene, M, ada 10 komponen senyawa yang terbesar dengan metode enflurasi dan beberapa senyawasenyawa tersebut merupakan senyawa aromatik

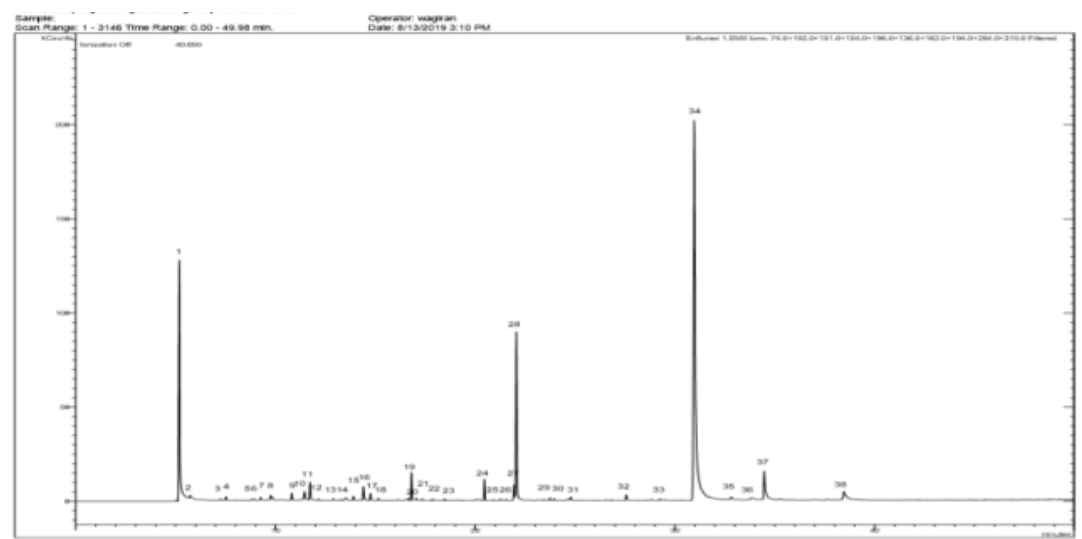

Gambar 4: Hasil Kromatografi metode enflurasi

Tabel 5: Tabel komponen senyawa bunga kopi metode enflurasi

\begin{tabular}{|c|c|c|c|c|}
\hline No & Waktu & Komponen & $\%$ Kecocokan & $\%$ Area \\
\hline 1 & 5,170 & \multirow{2}{*}{$\begin{array}{c}\text { 4-Hydroxybenzothiophene; } \mathrm{M}<\text { Mobam> } \\
\text { Cyclohexen, 1-methyl-(1- } \\
\text { mwthylethylidene)- }\end{array}$} & 53,43 & 20,66 \\
\hline 2 & 11,735 & & 43,98 & 1,38 \\
\hline 3 & 14,414 & $\begin{array}{l}\text { 3- Cyclohexen-1-ol, 4-methyl-1- } \\
\text { (methylethyl)- }\end{array}$ & 71,73 & 1,18 \\
\hline 4 & 16,827 & 1,3-Benzodioxole, 5-(-2-propenyl)- & 88,53 & 1,76 \\
\hline 5 & 20,463 & Trifluoraacetyl-epiisoborneol & 47,48 & 1,44 \\
\hline 6 & 21,954 & Undecanoic acid, 10-methyl-, methyl & 83,35 & 1,09 \\
\hline
\end{tabular}




\begin{tabular}{ccccc}
\hline \multicolumn{5}{c}{ ester } \\
7 & 22,049 & $1,3-$ Benzodioxole, 4-methoxy-6-(2- & 96,52 & 12,84 \\
8 & 30,985 & propenyl)- & 96,19 & 50,07 \\
9 & 34,475 & Caffeine & 83,34 & 1,47 \\
& 38,462 & Hexadecanoic acid, ethyl ester & 53,73 & 1,58 \\
\hline
\end{tabular}

\section{Ada 3 komponen senyawa yang paling besar yaitu:}

1. Caffein

2. 4-Hydroxybenzothiophene, M.

3. 1,3-Benzoldioxole,5-(2-properyl)

Kafein adalah senyawa alkaloid xantina berbentuk kristal dan berasa pahit yang bekerja sebagai obat perangsang psikoaktif dan diuretik ringan. Kafeina dijumpai secara alami pada bahan pangan seperti biji kopi, daun teh dan tumuhan lainnya. Pada tumbuhan, ia berperan sebagai pestisida alami yang melumpuhkan dan mematikan serangga-serangga tertentu yang memakan tanaman tersebut.

Penelitian ini telah menunjukkan bahwa kandungan terbesar dari minyak bunga kopi dengan metode enflurasi adalah kafein. Dua senyawa yang lain merupakan senyawa aromatic yang menyebabkan hasil uji organoleptik terhadap aroma dari metode ini menyerupai bunga kopi.

\section{Metode Maserasi}

Berdasarkan kromatogram pada bunga kopi terdeteksi 45 puncak dimulai dari komponen volatile nomor 6 yang muncul pada waktu retensi 14,474 menit dengan \% area 1.77. Komponen pertama tersebut adalah nonadecane, M, ada 15 komponen senyawa yang terbesar dengan metode enflurasi dan beberapa senyawa-senyawa tersebut merupakan senyawa aromatik

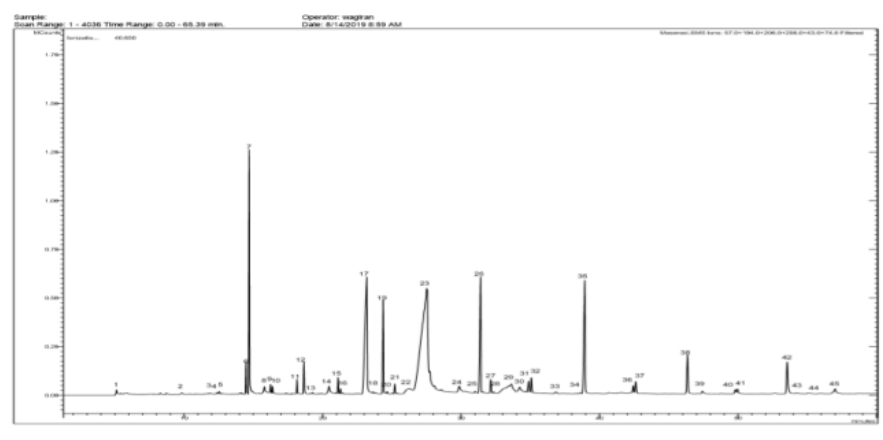

Gambar 5. Hasil Kromatografi metode maserasi

Tabel 6: Tabel komponen senyawa bunga kopi metode maserasi

\begin{tabular}{ccccc}
\hline No & Waktu & Komponen & $\begin{array}{c}\% \\
\text { Kecocokan }\end{array}$ & $\%$ Area \\
\hline 1 & 14,474 & Nonadecane & 64,25 & 1,77 \\
2 & 14,698 & Pentanoic acid, 5-hydroxy-, 2,4-di-t-butylphenyl & 79,85 & 13,46 \\
3 & 18,649 & esters & 41,95 & 1,93 \\
4 & 20,479 & Nonadecane & 75,14 & 1,00 \\
5 & 23,18 & Tetradecane & 78,42 & 20,33 \\
6 & 24,389 & 1,4-Dimethyl-4,5,7,8-tetrahydromoimidazo- & 30,36 & 6,80 \\
7 & 27,376 & 44,5-E]-1,4-diazepin-5,6(6H)-dione & 78,51 & 4,46 \\
8 & 31,345 & Tritetracontane & 30,99 & 10,32 \\
\hline
\end{tabular}




\begin{tabular}{ccccc}
\hline 9 & 32,158 & 1-methylbutyl hexadecanoate & 88,68 & 1,16 \\
10 & 33,628 & 9-Octadecenoic acid (Z)-, 2-hydroxy-1- & 61,14 & 1,82 \\
11 & 35,089 & (hydroxymethyl)ethyl ester & 30,66 & 1,15 \\
12 & 38,901 & Triteracontane & 32,19 & 11,83 \\
13 & 42,626 & Triteracontane & 27,33 & 1,01 \\
14 & 53,595 & 1-Decanol, 2-hexyl- & 36,35 & 3,68 \\
15 & 60,446 & 1-Hentetracontanol & 39,90 & 4,01 \\
\hline
\end{tabular}

Ada 3 komponen senyawa yang paling besar yaitu:

1. 1,4-Dimethyl-4,5,7,8-tetrahydroimidazo-[4,5-E]-1,4-diazepin-5,8(6H)-dione 1,4Dimethyl-4,5,7,8-tetrahydroimidazo-[4,5-E]-1,4-diazepin-5,8(6H)-dione.

2. Pentanoic acid, 5-hydroxy-, 2,4-di-t-butylphenyl esters

3. Triteracontane.

Senyawa1,4-Dimethyl-4,5,7,8-etrahydroimidazo- $\quad[4,5-\mathrm{E}]-1,4-d i a z e p i n-5,8(6 \mathrm{H})-$ dione 1,4-Dimethyl-4,5,7,8-tetrahydroimidazo-[4,5-E]-1,4-diazepin-5,8(6H) -dione merupakan senyawa aromatic yang ditemukan dalam penelitian ini dengan metode maserasi.

\section{Metode Hidrosol}

Berdasarkan kromatogram pada bunga kopi terdeteksi 23 puncak dimulai dari komponen volatile nomor 1 yang muncul pada waktu retensi 9.784 menit dengan \% area 1.22. Komponen pertama tersebut adalah cyclohexene,1-methyl-5-(1methylethenyl)-,(s), ada 12 komponen senyawa yang terbesar dengan metode hidrosol dan beberapa senyawa-senyawa tersebut merupakan senyawa aromatic

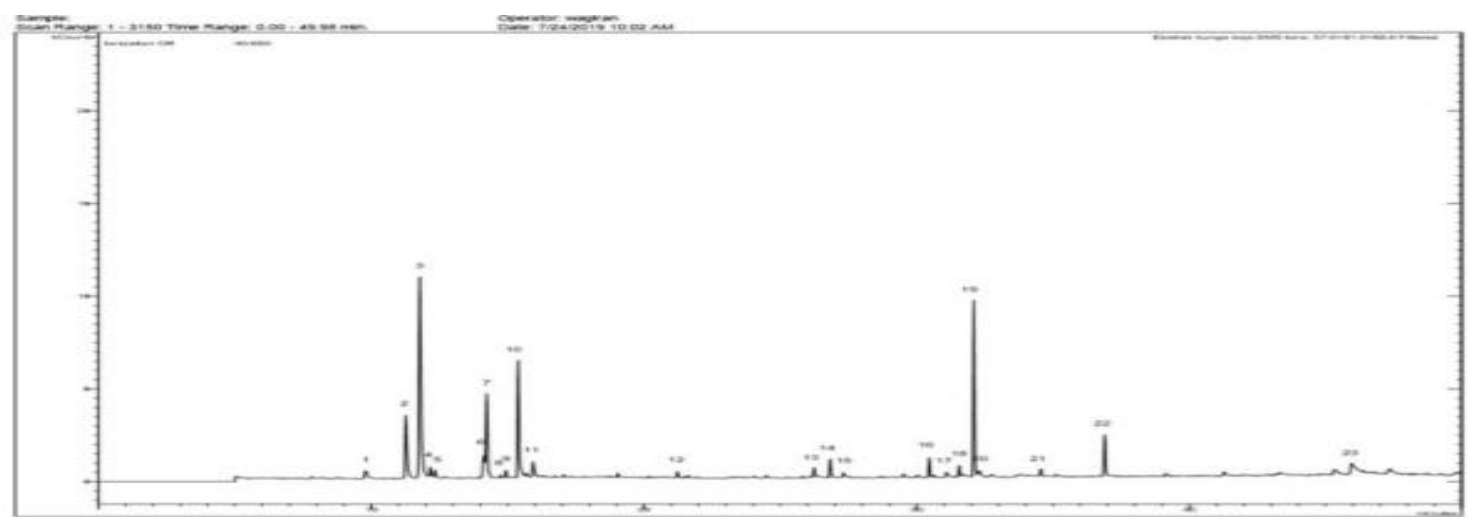

Gambar 6: Hasil Kromatografi metode Hidrosol

Tabel 7. Tabel komponen senyawa bunga kopi dengan metode hydrosol.

\begin{tabular}{|c|c|c|c|c|}
\hline No & Waktu & Komponen & $\begin{array}{l}\text { \% } \\
\text { Kecocokan }\end{array}$ & $\%$ Area \\
\hline 1 & 9,784 & Cyclohexene,1-methyl-4-(1-methylethenyl)-,(S)- & 73,89 & 1,22 \\
\hline 2 & 11,272 & $\begin{array}{l}\text { Alpha, -Methyl-alpha-[4-methyl-3-pentenyl] } \\
\text { oxyranemethanol }\end{array}$ & 88,19 & 8,65 \\
\hline 3 & & $\begin{array}{l}\text { Alpha, -Methyl-alpha-[4-methyl-3-pentenyl] } \\
\text { oxyranemethanol }\end{array}$ & 80,07 & 28,56 \\
\hline 4 & & $\begin{array}{l}2 \mathrm{H}-\text { Pyran-3-ol,6-ethenyltetrahydro-2,2,6- } \\
\text { trimethyl- }\end{array}$ & 92,34 & 2,67 \\
\hline 5 & 14,123 & $\begin{array}{l}\text { 2H-Pyran-3-ol,6-ethenyltetrahydro-2,2,6- } \\
\text { trimethyl- }\end{array}$ & 97,52 & 10,23 \\
\hline 6 & & Geranyl vinyl ether & 47,46 & 14,39 \\
\hline
\end{tabular}




\begin{tabular}{lllll}
\hline 7 & & Cyclohexasiloxane, dodecamethyl- & 95,76 & 1,57 \\
8 & & Hydroxylamine, O-decyl- & 25,31 & 1,98 \\
9 & 30,46 & $3,7,11,15-T e t r a m e t h y l-2-h e x a d e c e n-1-o l$ & 65,45 & 1,76 \\
10 & 31,555 & $3,7,11,15-T e t r a m e t h y l-2-h e x a d e c e n-1-o l$ & 62,93 & 1,05 \\
11 & 32,098 & Nonadecane & 19,92 & 16,22 \\
12 & 36,892 & Nonadecane & 21,53 & 4,17 \\
\hline
\end{tabular}

Ada 3 komponen senyawa yang paling besar yaitu:

1. alpha,-methyl-,alpha,-(4-methyl-3penteny)oxyranemethanol

2. Nonadecane

3. Geranyl vinyl ether. kopi.

Ketiga senyawa diatas adalah senyawa aromatic yang terdapat dalam bunga

\section{SIMPULAN}

Berdasarkan hasil penelitian diperoleh rendemen yang paling tinggi dengan dengan metode enflurasi, akan tetapi aroma yang dihasilkan hanya menyerupai bunga kopi sehingga metode terbaik untuk ekstraksi bunga kopi adalah dengan metode hydrosol. Aroma yang dihasilkan dengan metode hydrosol sangat menyerupai bunga kopi. Karakteristik yang dihasilkan metode maserasi aroma yang dihasilkan berdasarkan uji organoleptik terhadap aroma tidak menyerupai dengan bunga kopi. Warna minyak bunga kopi hasil ekstraksi dari metodeenflurasi adalah kekuningkuningan Komponen senyawa yang dihasilkan paling banyak adalah kafein. Karakteristik yang dihasilkan metode enflurasi aroma yang dihasilkan berdasarkan uji organoleptik terhadap aroma hanya menyerupai dengan bunga kopi. Warna minyak bunga kopi hasil ekstraksi dari metode enflurasi adalah kecoklatan Komponen senyawa yang dihasilkan paling banyak adalah 1,4-Dimethyl -4,5,7,8tetrahydroimidazo -[4,5-E] -1,4-diazepin-5,8(6H) -dione 1,4-Dimethyl - 4,5,7,8tetrahydroimidazo-[4,5-E]-1,4-diazepin-5,8(6H)-dione. Karakteristik yang dihasilkan metode maserasi aroma yang dihasilkan berdasarkan uji organoleptik terhadap aroma sangat menyerupai dengan bunga kopi. Warna minyak bunga kopi hasil ekstraksi dari metode hidrosol adalah jernih Komponen senyawa yang dihasilkan paling banyak adalah alpha,-methyl-,alpha,-(4-methyl-3penteny) oxyranemethanol.

\section{SANWACANA}

Terimaksih kepada Laboratorium Terpadu dan Sentra Inovasi Teknologi (LTSIT) Universitas Lampung.yang telah memberikan kontribusi dalam penyelesaian penelitian ini.

\section{DAFTAR PUSTAKA}

BPS provinsi Lampung,2017.

Edris,A.E, R.Chizola and C. Frans.2008. Isolation and characteristization of volatile aroma compounds from the concrete hendspace and the absolute of jasminum sambac (L). Art (Oleaceae) flavor grown in Egypt. European Food Research Tehnologi. 
Ekawati Lolyta A. 2011. Ekstraksi minyak atsiri bunga krisan (chrysanthemum cineranaethalium) dengan pelarut ethanol dan $n$-heksana. Tugas akhir. Program studi teknik kimia Universitas Negeri Semarang. Semarang

Fajrin Nurhayati. 2017.kajian pengembangan agroindustri minyak atsiri berbasis bunga di provinsi Lampung.Skripsi. Universitas Lampung. Bandar Lampung.

Fachrudin Fachrudin, Agi lqbal Velayas, Mahfud Mahfud dan Lailatul Qadariyah. 2016. Ekstraksi Minyak Bunga Cempaka dengan metode hidrodistilation dengan aliran udara. Jurusan Teknik Kimia, Fakultas Teknologi Industri, Institut Teknologi Sepuluh Nopember (ITS). Surabaya.

Guenther, E.2011. Alih Bahasa S. Ketaren. Minyak Atsiri.jilid1. UI Press. Jakarta.

Haynes, W.M. Lide, D.R. Bruno, 2014. CRC handbook of chemistry and Physics. CRC Press of taylor and friends grup. International Standar book number 13.

Huda, Muhammad Nurul. 2010. Pengambilan minyak bunga melati menggunakan lemak sapi- kambing-ayam. Skripsi. Program studi teknik kimia Universitas Negeri Semarang. Semarang..

Jimenez-Carmona, M.M., Ubera, J.L., Luque de Castro, M.D. 1999.Comparison of continous subcritical water extraction and hydrodistillation of marjoram essentiel oil, Journal of Chromatography A, 855: 625-632

Ketaren, S. 1986. Pengantar Teknologi Minyak Dan Lemak. UI Press. Jakarta.

Murhadi. 2002. Isolasi dan karakteristik komponen anti bakteri dari biji atung (parinarium glaberiam hassk). Disertasi. Program pascasarjana Institut Pertanian Bogor. Bogor.

Mulyani, HRA. Ekstraksi dan karakteristik minyak bijimengkudu (moriada citrofolla L). 2006. Tesis. Program studi pascasarjana Universitas Lampung. Bandar Lampung.

Isoa Nohara, Makoto Emura, Takaaki Toyoda, Tsuneyoshi Kanishawa. 1997. Epoxygeraniol and epoxynerol from coffee flower.jurnal.

Sani Sabrina Nazma, Rofiah Rahmawati dan Mahfud. 2012. Pengambilan minyak atsiri dari melati dengan metode enflurasi dan ekstraksi pelarut menguap.Jurnal Teknik Universitas Sepuluh November Surabaya. Surabaya 1:1-4

Scognamiglio,J. L,jones,C.S. Letizia and A.M. Api.2012. Fragnance Material Review on Cis-Jasmone. Food And Chemichal Toxicology Journal 3.

Sulaiman Ismail. 2014. Perbandingan beberapa metode ekstraksi minyak atsiri pada minyak nilam (pogostemoncablin). Jurnal Teknologi Industri Pertanian.

Utomo Suratmin. 2016. Pengaruh konsentrasi pelarut $n$-heksana terhadap rendemen hasil ekstraksi minyak biji alpukat untuk pembuatan krim pelembab kulit. Konversi vol 5:1.Universitas muhammadiyah Jakarta. Jakarta.

Yulianingsih, D.Amarsi, dan Sabari.S, 2007.Teknik Enflurasi dalam proses pembuatan minyak mawar.Balai Penelitian Tanaman Hias. Cianjur.

Wahyuni dan Made. 1998. Teknologi pengolahan pangan hewani tepat guna. CV Akademika Pressindo. Jakarta.

Wulandari,I. 2011. Teknologi Ekstraksi Dengan Metode Maserasi. Gramedia. Surakarta 